\title{
Nothing Endures but Change
}

A review of: Lagasse E, Connors H, Al-Dhalimy M, Reitsma M, Dohse M, Osborne L, Wang X, Finegold M, Weissman IL, Grompe M 2000 Purified hematopoietic stem cells can differentiate into hepatocytes in vivo. Nature Med 6:1229-1234

$\mathrm{T}$ HIS LATEST REPORT from the group of Marcus Grompe represents another step in the exciting progress with stem cells. Working with a murine model of hereditary tyrosinemia type 1 (HT1, fumaryl acetoacetate hydrolase [FAH] deficiency), Grompe's group has investigated the problem of repopulating a defective liver with extraneous hepatocytes. They showed that hepatocytes with the normal FAH gene (naturally or after gene transduction) have a proliferative advantage over abnormal hepatocytes with HT1 (1). In their model, normal adult differentiated hepatocytes retain a formidable capacity for repopulating a damaged liver (approximately 70 cell doublings), but these hepatocytes, which they term "regenerative transplantable hepatocytes," did not form bile duct epithelial cells or other cellular elements of the normal liver. Therefore, a more plastic progenitor cell must exist.

In the current paper the authors show that this progenitor cell is the hematopoietic stem cell. Female $\mathrm{FAH}^{-} / \mathrm{FAH}^{-}$ mice were subjected to myeloablation and then bone marrow transplantation with unfractionated bone marrow from syngeneic normal male mice; three weeks after transplantation chemical treatment for HT1 was withheld and liver damage ensued. Livers from survivors of this selection strategy were later found to consist of $30-50 \%$ donorderived hepatocytes. Further experiments established that the cells in the donor marrow capable of rescuing the defective livers had the characteristics of hematopoietic stem cells (namely: c-kit positive, Lin negative, Sca-1 negative).

Several recent studies indicate that cells in the adult bone marrow are capable of becoming differentiated parenchymal cells in other organs: myocytes (2), neurons $(3,4)$, and hepatocytes. Using various combinations of bone marrow transplantation and toxic liver damage in rats, Petersen and colleagues showed that a cell in the bone marrow could form both the hepatic epithelial precursor cell known as an "oval cell" and hepatocytes (5). In a murine model using gender-mismatched bone marrow transplantation, Theise and colleagues demonstrated that cells derived from bone marrow formed hepatocytes in the absence of liver injury (6). Their observations raise the possibility that bone marrow derived stem cells replenish hepatocytes under normal physiological conditions.

The same mechanisms appear to operate in the human liver. When stressed, differentiated human hepatocytes demonstrate considerable proliferative capacity. Although the existence of human "oval cells" is controversial, progenitor cells including some with characteristics of bone marrow-derived cells have been identified in human livers (7). Working with human liver specimens, from gender-mismatched bone marrow or liver transplant recipients, Theise and colleagues showed that cells derived from the bone marrow could differentiate into mature hepatocytes or bile duct epithelial cells, even in the absence of ongoing liver damage (8). Without liver injury, engrafted hepatocytes were found as isolated cells in the lobule. With injury, an oval-cell-like transition form was identified. Alison and colleagues (9) found similar results in a larger number of patients.

Though not in a human system, the new paper from Grompe's group is noteworthy. Unlike previous studies, it specifies the characteristics of the candidate bone marrow cell, which can form hepatocytes as those of the pluripotent hematopoietic stem cell. These findings have important therapeutic implications. Working with hematopoietic stem cells poses fewer practical and ethical problems than strategies involving embry- onic stem cells. Routine bone marrow transplantation might be curative for some metabolic liver diseases. Alternatively, it might be possible to perform autologous transplantation using the affected individual's own hematopoietic stem cells transduced with the normal gene. Ongoing liver damage would favor repopulation but might not be prerequisite.

These fascinating studies emphasize that organs that appear to be static are in a continuous state of flux. The mechanisms of such change may provide opportunities for innovative therapies.

1. Overtuf K, Al-Dhalimy M, Tanguay R, Brantly M, Ou C-N, Finegold M, Grompe M 1996 Hepatocytes corrected by gene therapy are selected in vivo in a murine model of hereditary tyrosinaemia type I. Nat Genet 12:266-273

2. Ferrari G, Cusella-De Angelis G, Coletta M, Paolucci E, Stormaiuolo A, Cossu G, Mavilio Fl 1998 Muscle regeneration by bone marrow-derived myogenic progenitors. Science 279:1528-1530

3. Brazelton TR, Rossi FMV, Keshet GI, Blau HM 2000 From marrow to brain: expression of neuronal phenotypes in adults mice. Science 290:1775-1779

4. Mezey E, Chandross KJ, Harta G, Maki RA, McKercher SR 2000 Turning blood into brain: cells bearing neuronal antigens generated in vivo from bone marrow. Science 290:1779-1782

5. Petersen BE, Bowen WC, Patrene KD, Mars WM, Sullivan AK, Murase N, Boggs SS, Greenberger JS, Gof JP 1999 Bone marrow as a potential source of hepatic oval cells. Science 284:1168-1170

6. Theise ND, Badve S, Saxena R, Henegariu O, Sell S, Crawford JM, Krause DS 2000 Derivation of hepatocytes from bone marrow cells in mice after radiation-induced myeloablation Hepatology 31:235-240

7. Baumann U, Crosby HA, Ramani P, Kelly DA, Strain AJ 1999 Expression of the stem cell factor receptor c-kit in normal and diseased pediatric liver: identification of a human hepatic progenitor cell? Hepatology 30:112-117

8. Theise ND, Nimmakayalu M, Gardner R, Illei PB Morgan G, Teperman L, Henegariou O, Krause DS 2000. Liver from bone marrow in humans. Hepatology 32:11-16

9. Alison MR, Poulsom R, Jeffrey R, Dhillon AP, Quaglia A, Jacob J, Novelli M, Prentice G, Williamson J, Wright NA 2000 Hepatocytes from nonhepatic adult stem cells. Nature 406:257

The Hospital for Sick Children

Division of Gastroenterology Nutrition

Room 8267, Black Wing

555 University Avenue

Toronto, Ontario

Canada M5G 1 X8 